\title{
$\alpha, \beta$-Thujone suppresses human placental choriocarcinoma cells via metabolic disruption
}

\author{
Jin-Young Lee ${ }^{1}$, Hahyun Park², Whasun Lim³ and Gwonhwa Song² \\ ${ }^{1}$ Department of Pharmacology and Toxicology, Medical College of Wisconsin, Milwaukee, Wisconsin, USA, ${ }^{2}$ Institute \\ of Animal Molecular Biotechnology and Department of Biotechnology, College of Life Sciences and Biotechnology, \\ Korea University, Seoul, Republic of Korea and ${ }^{3}$ Department of Food and Nutrition, Kookmin University, Seoul, \\ Republic of Korea
}

Correspondence should be addressed to W Lim or G Song; Email: wlim@kookmin.ac.kr or ghsong@korea.ac.kr

\begin{abstract}
$\alpha, \beta$-Thujone is a natural terpenoid found in many medicinal herbs, such as Artemisia absinthium (wormwood), that exhibits antioxidant, anti-diabetic, and anti-tumorigenic effects. $\alpha, \beta$-Thujone has numerous functions; it serves as a food ingredient, cosmetic additive, and medicinal remedy. Although the therapeutic properties of $\alpha, \beta$-thujone were previously revealed, a comprehensive description of the mechanisms of its anti-cancer potential in choriocarcinoma is yet to be provided. To our knowledge, this study is the first to demonstrate that $\alpha, \beta$-thujone attenuates JEG3 and JAR choriocarcinoma cells through a caspase-dependent intrinsic apoptotic pathway. Moreover, $\alpha, \beta$-thujone was demonstrated to induce a global mitochondrial defect and ER stress in choriocarcinoma by causing mitochondrial depolarization, calcium overload, and metabolic alterations, thereby leading to energy deprivation, which eventually contributes to the increase in apoptosis of choriocarcinoma cells. Herein, we also revealed the synergistic anti-cancer activity of $\alpha, \beta$-thujone via its sensitization effect on paclitaxel in choriocarcinoma cells. Altogether, our findings suggest that $\alpha, \beta$-thujone is a novel, natural pharmacological compound that can be used to treat human placental choriocarcinoma.

Reproduction (2020) 159 745-756
\end{abstract}

\section{Introduction}

Placentation is a crucial process in the maintenance and development of conceptus, which functionally transfers nutrients and oxygen from maternal blood (Gude et al. 2004). During placental development, excessive proliferation and the local invasion of trophoblast occur in the maternal endometrium under tight control (Turco \& Moffett 2019). However, dysregulation of the trophoblast and the functions of the placenta result in placental cyst instead of an embryo, which may result in cancerous placenta from normal pregnancy called choriocarcinoma (Jiao et al. 2016). Choriocarcinoma is easily metastasized in the lung, liver, and brain. In addition, this type of metastatic cancer is considered to be severe and its therapeutic outcomes are skeptical (Nabers et al. 1990, Kang et al. 2002, Dadlani et al. 2010). In the clinic, human chorionic gonadotrophin (hCG) is a diagnostic marker of choriocarcinoma as it is mainly produced by JEG-3 choriocarcinoma cells (Handschuh et al. 2007, Fournier 2016). An increase in hCG concentration implies the advanced tumor stage and predictable metastasis in choriocarcinoma patients (Heller 2018). Despite the establishment of the etoposide, methotrexate, actinomycin, cyclophosphamide, vincristine (EMA)
CO) regimen as a conventional chemotherapeutic strategy against choriocarcinoma, 20-30\% of high-risk patients do not respond to this regimen (Bower et al. 1997). Hence, taxanes, such as paclitaxel, have been suggested as an alternative reagent to overcome EMA/ CO resistance. A case report also proved the significant contribution of paclitaxel treatment in choriocarcinoma (Joshua et al. 2004).

Anti-cancer compounds from natural-derivatives have long been suggested to overcome cancer cell drug resistance against conventional chemotherapy (Chang et al. 2000, Lee et al. 2018, Wroblewska-Kurdyk et al. 2019). Among them, $\alpha, \beta$-thujone was identified as a promising natural compound from thuja oil, a functional component in absinthe, wormwood, and other herbal medicines. $\alpha, \beta$-Thujone has been demonstrated to exhibit different therapeutic potentials against many diseases. Previously, thuja extracts were suggested to serve as anti-cancer drugs against melanoma (Biswas et al. 2011), mammary tumor (Ojeswi et al. 2010), breast cancer (Frenkel et al. 2010), and glioblastoma (Pudelek et al. 2019). However, studies on the anti-cancer potential of $\alpha, \beta$-thujone in placental choriocarcinoma and its effects on mitochondria and ER stress have not been performed. 
In the present study, we sought to reveal the antitumorigenic effect of $\alpha, \beta$-thujone in JEG3 and JAR choriocarcinoma cell lines via a comprehensive mechanistic analysis. Based on our findings, we could demonstrate the effects of $\alpha, \beta$-thujone on the proliferation and viability of choriocarcinoma cells and reveal the molecular mechanisms of the apoptotic pathways. Furthermore, by determining the effects of $\alpha, \beta$-thujone on ER and mitochondrial stress, we found that metabolic disruption could attenuate choriocarcinoma cells. $\alpha, \beta$-Thujone was also found to sensitize cancer cells from paclitaxel response in JEG3 and JAR cells. Such findings imply its promising pharmaceutical property against gynecological cancers. Altogether, the present study revealed the strong pharmacological potential of $\alpha, \beta$-thujone by demonstrating the multiple molecular mechanisms that is associated with its function.

\section{Materials and methods}

\section{Reagents}

$\alpha, \beta$-Thujone (Cat. No: 89230) was obtained from SigmaAldrich. ZVAD-FMK (Cat. No: 627610) was obtained from Calbiochem. Antibodies against MCL-1, BCL2, BCL2L1, PARP, HSPA5, p-EIF2AK3, ATF4, DDIT3, and ACTB were obtained from Cell Signaling Technology. MG-132 (Cat. No: M7449), Hoechst (Cat. No: B2261), and Propidium iodide (Cat. No: P4170) were obtained from Sigma-Aldrich.

\section{Cell culture and chemical treatment}

The choriocarcinoma cell lines, JEG3 and JAR, were purchased from the American Type Culture Collection (ATCC). Cells were cultured in 1X GlutaMAX included- RPMI 1640 medium (Thermo Fisher Scientific) containing $10 \%$ fetal bovine serum (FBS) and $1 \%$ penicillin-streptomycin. JEG3 and JAR cells were maintained at $37^{\circ} \mathrm{C}$ with $5 \% \mathrm{CO}_{2}$ and seeded in culture dishes at 20,000 cells $/ \mathrm{cm}^{2}$ for $24 \mathrm{~h}$ before chemical treatment. Thereafter, cells were treated with the indicated concentrations of $\alpha, \beta$-thujone, and an equal volume of DMSO was administered to serve as the vehicle control.

\section{Cell viability and proliferation assay}

The proliferation and viability of JEG3 and JAR cells were determined by a trypan blue exclusion assay and cells were counted using a hemocytometer under brightfield microscopy (Thermo Fisher Scientific) for quantification. To support the findings of the trypan blue exclusion assay, an MTT assay as also performed to demonstrate the metabolic activity of NADHdependent oxidoreductase. For this assay, 10,000 cells were seeded in each well of a 96-well plate for $24 \mathrm{~h}$. Thereafter, the indicated concentrations of $\alpha, \beta$-thujone were added and the mixtures were incubated for $48 \mathrm{~h}$ to perform the MTT assay. For the MTT assay, $25 \mathrm{mg}$ of MTT reagent (3-(4,5-dimethylthia zol-2-yl)-2,5-diphenyl-tetrazolium bromide) was dissolved in $5 \mathrm{~mL}$ PBS as stock solution; $100 \mu \mathrm{L}$ of the MTT reagent was added to the wells containing $\alpha, \beta$-thujone, and the plate was incubated at $37^{\circ} \mathrm{C}$ with $5 \% \mathrm{CO}_{2}$ for $3 \mathrm{~h}$. After incubation, 100 $\mu \mathrm{L}$ of DMSO was added and the plate was incubated at room temperature for $2 \mathrm{~h}$ in darkness. The absorbance was analyzed at $490 \mathrm{~nm}$ using a plate reader. To support our results, we also performed a Cell Titer-Glo Luminescent assay (Promega), a homogeneous method that can be used to demonstrate viable cells according to ATP production. This assay was performed according to the manufacturer's procedure.

\section{Apoptosis evaluation}

For the apoptosis analysis, in situ staining dyes, including Hoechst 33342 (Sigma-Aldrich) and propidium iodide (Sigma-Aldrich), were employed to evaluate the percentage of apoptotic and necrotic cells through nuclei fragmentation and condensation. A Caspase-Glo 3/7 Assay (Promega) was used to determine the enzymatic activity of caspases $3 / 7$; this assay was performed according to the manufacturer's procedure. To verify the apoptotic effect of $\alpha, \beta$-thujone, we also performed Annexin/PI analysis by using a flow cytometer. For Annexin V/PI staining, $1.5 \mu \mathrm{g} / \mathrm{mL}$ of Annexin and $2 \mu \mathrm{g} / \mathrm{mL}$ of Pl were dissolved in a binding buffer as final concentration. Cells were stained with $100 \mu \mathrm{L}$ of Annexin V/PI solution at room temperature for $15 \mathrm{~min}$ in darkness. After incubation, $400 \mu \mathrm{L}$ of the binding buffer was added and the sample was kept in darkness before flow cytometer analysis. For the flow cytometer analysis, we adjusted the cell population in the appropriate excitation laser (FL1, FL2, and FL3) and optimized the FSC and SSC voltage. After compensation to avoid channel interference, we measured each of the cell population in each division.

\section{Morphological analysis}

For morphological analysis, 20,000 cells $/ \mathrm{cm}^{2}$ of JEG3 and JAR cells were seeded in a 6-well plate for $24 \mathrm{~h}$. Thereafter, cells were exposed to $\alpha, \beta$-thujone. After $48 \mathrm{~h}$ of $\alpha, \beta$-thujone treatment, cell morphology was determined using Differential Quik (Diff-Quik) staining (Polysciences, Warrington, PA, USA), according to the manufacturer's procedure.

\section{Spheroid formation}

To evaluate the spheroid forming capacity of cells, $100 \mu \mathrm{L}$ of 10,000 cells were seeded in each well of a round bottom plate; each well contained $300 \mu \mathrm{g} / \mathrm{mL}$ of $\alpha, \beta$-thujone. Thereafter, the plate was incubated at $37^{\circ} \mathrm{C}$ in $5 \% \mathrm{CO}_{2}$ for 7 to 10 days. The $3 \mathrm{D}$ graphics were generated by Revisp software.

\section{Western blot}

Proteins were extracted from whole-cell, and their concentration was evaluated using the Bradford protein assay (Bio-Rad). Proteins were denatured, separated by sodium dodecyl sulfate-PAGE (SDS-PAGE), and transferred onto nitrocellulose membranes. Blots were developed using enhanced chemiluminescence detection (SuperSignal West Pico, Pierce) and quantified as described previously (Lim et al. 2018). 


\section{Proteasome activity assay}

The analysis of proteasome activities was conducted using a Proteasome-Glo cell-based assay (Promega), according to the manufacturer's procedure. In brief, 10,000 cells/well were seeded with $100 \mu \mathrm{L}$ of complete media in a 96-well plate before $24 \mathrm{~h}$ of chemical treatment. Thereafter, $\alpha, \beta$-thujone was administered at the indicated concentrations for $48 \mathrm{~h}$ at $37^{\circ} \mathrm{C}$ in a $5 \% \mathrm{CO}_{2}$ incubator. After $\alpha, \beta$-thujone treatment, the luciferin reagent was prepared, and each proteasome substrate and inhibitor were mixed in the Proteasome-Glo ${ }^{\mathrm{TM}}$ Reagent. After 30 min of incubation at room temperature, $100 \mu \mathrm{L}$ of the mixture was added to the cells treated with $\alpha, \beta$-thujone. After an additional 10 min incubation, luminescence was measured by a luminometer.

\section{Mitochondrial membrane potential analysis}

Mitochondrial membrane potential was analyzed using a mitochondrial staining kit (Sigma-Aldrich), according to the manufacturer's procedure. In brief, $20,000 / \mathrm{cm}^{2}$ cells were seeded in a 6-well plate with $2 \mathrm{~mL}$ of complete media prior to $24 \mathrm{~h}$ of chemical treatment. $\alpha, \beta$-Thujone was then administered at the indicated concentrations for $48 \mathrm{~h}$ at $37^{\circ} \mathrm{C}$ in a $5 \% \mathrm{CO}_{2}$ incubator. After treatment with $\alpha, \beta$-thujone, cells were stained with JC-1 staining buffer and incubated for $20 \mathrm{~min}$ at $37^{\circ} \mathrm{C}$ in a $5 \% \mathrm{CO}_{2}$ incubator. The stained cells were washed, and the fluorescence signal was analyzed by flow cytometry.

\section{Mitochondrial calcium analysis}

Mitochondrial calcium levels were analyzed with Rhod-2 AM reagent (Thermo Fisher Scientific). Briefly, 20,000/cm² cells were seeded in a 6 -well plate with $2 \mathrm{~mL}$ of complete media prior to $24 \mathrm{~h}$ of chemical treatment. $\alpha, \beta$-Thujone was then administered at the indicated concentrations for $48 \mathrm{~h}$ at $37^{\circ} \mathrm{C}$ in a $5 \% \mathrm{CO}_{2}$ incubator. After $\alpha, \beta$-thujone treatment, cells were stained with Rhod-2 AM and incubated for $30 \mathrm{~min}$ at $37^{\circ} \mathrm{C}$ in a $5 \% \mathrm{CO}_{2}$ incubator in darkness. The stained cells were briefly washed, and the fluorescence signal was analyzed using a flow cytometer.

\section{Seahorse}

For the mitochondrial stress analysis, we evaluated the oxygen consumption rate (OCR) by measuring OXPHOS. The sequential injection of oligomycin, FCCP, rotenone, and antimycin (mitochondrial complex I and III inhibitors) enabled the quantification of basal respiration, proton leak, maximal respiration, non-mitochondrial respiration, ATP production, and spare respiratory capacity using Seahorse with a mitochondrial stress analysis kit (Agilent Technologies).

\section{Statistical analysis}

Data are expressed as mean \pm S.D., and significance was estimated by one-way or two-way ANOVA, as further described in the figure legends. Post-hoc analyses were performed using Graph Pad Prism 7 software. Statistical significances were indicated by $P$-values $<0.05$ and are presented as follows in the legend: $* P<0.05, * * P<0.01, * * * P<0.001$; posthoc analyses Dunnett; Sidak). All histograms represent the mean \pm S.D. of at least three independent experiments.

\section{Results \\ Anti-cancer potential of $\alpha, \beta$-thujone in human placental choriocarcinoma cells}

We sought to analyze the anti-cancer potential of $\alpha, \beta$ thujone on the proliferation and viability of JEG3 and JAR cells in time- and dose-dependent manners. As shown in Fig. 1, cell viabilities were dose-dependently reduced by treatment with 100 to $300 \mu \mathrm{g} / \mathrm{mL}$ of $\alpha, \beta$ thujone in both JEG3 and JAR cells (Fig. 1A). In addition, cell proliferation was completely abrogated by treatment with $100 \mu \mathrm{g} / \mathrm{mL}$ of $\alpha, \beta$-thujone for $24 \mathrm{~h}$ (Fig. 1B). As the IC50 value was achieved at $48 \mathrm{~h}$ of treatment, an MTT assay was performed to confirm the anti-proliferative effects of $\alpha, \beta$-thujone treatment at this selective time point in the JEG3 and JAR human choriocarcinoma cell lines (Fig. 1C). Our results clearly demonstrate that cell proliferation was significantly inhibited in a dose-dependent manner in both JEG3 and JAR cells. In accordance with previous results, ATP production was more sensitively abrogated by $\alpha, \beta$-thujone treatment in both cell lines (Fig. 1D). In addition, we revealed that $\alpha, \beta$-thujone inhibits the anchorage-independent growth of choriocarcinoma cells by completely reducing JEG3 and JAR tumor spheroids (Fig. 1E). These results suggest that $\alpha, \beta$-thujone has a strong potential to exhibit anticancer efficacy against choriocarcinoma cells via inhibiting proliferation and inducing cell death.

\section{Caspase-dependent intrinsic apoptosis was induced by $\alpha, \beta$-thujone in human placental choriocarcinoma cells}

To identify the $\alpha, \beta$-thujone-mediated cell death modality, JEG3 and JAR cells were stained with Annexin/PI and treated with $\alpha, \beta$-thujone. Based on our findings, different aspects of cell death were dependent on the concentration of $\alpha, \beta$-thujone administered. According to our results, in JEG3 cells, $200 \mu \mathrm{g} / \mathrm{mL}$ of $\alpha, \beta$-thujone induced both early (nuclear fragmentation w/o PI) and late apoptosis (nuclear fragmentation w PI). In addition, $300 \mu \mathrm{g} / \mathrm{mL}$ of $\alpha, \beta$-thujone mainly increased late apoptosis and partial necrosis (w/o nuclear fragmentation w PI). In JAR cells, 100 and 200 $\mu \mathrm{g} / \mathrm{mL}$ of $\alpha, \beta$-thujone induced early apoptosis (nuclear fragmentation w/o Pl) and $300 \mu \mathrm{g} / \mathrm{mL}$ of $\alpha, \beta$-thujone mainly triggered necrosis (w/o nuclear fragmentation w PI) (Fig. 2A). To support these data, annexin and PI staining were performed with a flow cytometer following $\alpha, \beta$-thujone treatment in JEG3 and JAR cells (Fig. 2B). $\alpha, \beta$ Thujone sequentially induced early and late apoptosis in JEG3 and JAR cells, eventually causing necroptosis (Fig. 2C). Thus, we proceeded to investigate the activities 
A
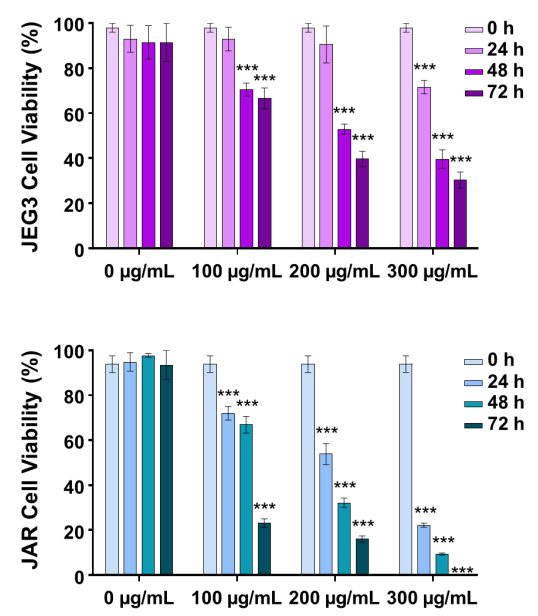

\section{$\mathrm{E}$}

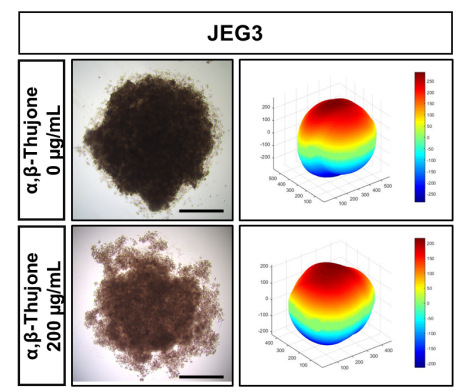

$\mathrm{B}$
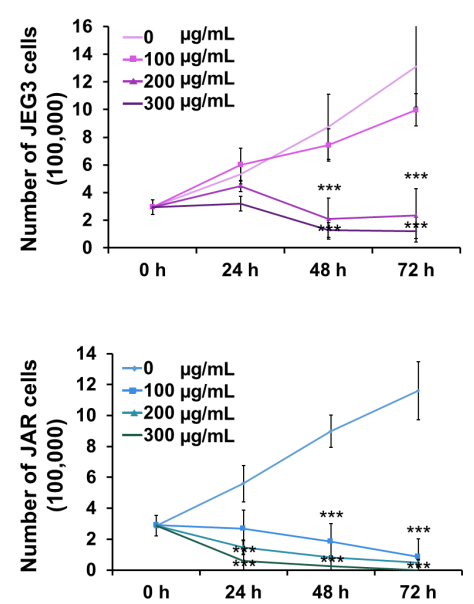
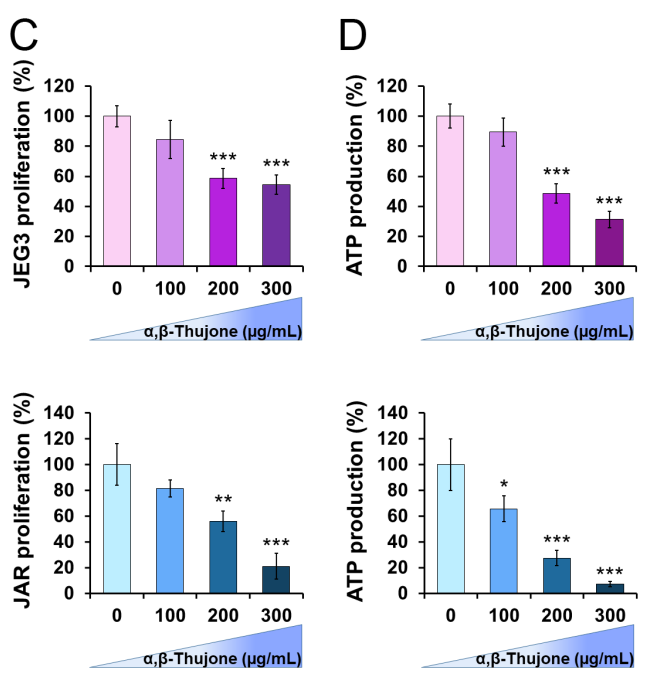

Figure 1 Effect of $\alpha, \beta$-thujone on the proliferation and viability of JEG3 and JAR cells. (A) The viability of JEG3 (upper panel) and JAR (lower panel) cells in response to dose- and time-dependent treatment with $\alpha, \beta$-thujone was measured by trypan blue exclusion assay. (B) The proliferation of JEG3 (upper panel) and JAR (lower panel) cells was analyzed by trypan blue exclusion assay in response to dose- and timedependent treatment with $\alpha, \beta$-thujone. (C) The effect of $\alpha, \beta$-thujone on the redox potential in JEG3 (upper panel) and JAR (lower panel) cells at $48 \mathrm{~h}$ was assessed by the tetrazolium dye (MTT) assay. (D) The effect of $\alpha, \beta$-thujone on intracellular ATP levels in JEG3 (upper panel) and JAR (lower panel) cells at $48 \mathrm{~h}$ was assessed via colorimetric analysis. (E) The effects of $\alpha, \beta$-thujone on anchorage-independent growth of choriocarcinoma cells were analyzed in JEG3 (left panel) and JAR (right panel) spheroids, and the spheroid forming ability was demonstrated using the 3D structures analyzed with the ReViSP software. The scale bar indicates $100 \mu \mathrm{m}$. Results are expressed as mean \pm S.D. of three independent experiments. Asterisk indicates a statistically significant difference compared to the control, as analyzed by Dunnett's test, one-, or two-way ANOVA $(* P<0.05 ; * * P<0.01 ; * * * P<0.001)$.

of caspases 3 and 7, which are well-known mediators of the intrinsic apoptotic cell death pathway, to determine the molecular pathway of apoptosis. Based on our findings, $\alpha, \beta$-thujone increased caspase $3 / 7$ activity, but this was overturned by pretreatment with the pancaspase inhibitor, ZVAD (Fig. 2D). Such findings clearly demonstrate that the anti-cancer property of $\alpha, \beta$-thujone is based on caspase-dependent canonical apoptosis in both JEG3 and JAR choriocarcinoma cells. As our previous data showed that apoptosis was mainly induced by $\alpha, \beta$-thujone, we analyzed the signal transduction cascade of apoptosis-related proteins according to $\alpha, \beta$ thujone treatment in JEG3 and JAR cells. In JEG3 cells, the expression of the anti-apoptotic proteins, MCL-1 and $\mathrm{BCl}-2$, were dose-dependently reduced by $\alpha, \beta-$ thujone (Fig. 3A). Interestingly, the protein expression level of BCL2L1 was completely inhibited from $100 \mu \mathrm{g} /$ $\mathrm{mL}$, the low concentration of $\alpha, \beta$-thujone, in JEG3 cells.
In accordance with these findings, the cleavage of the pro-apoptotic protein, PARP, was increased following treatment in JEG3 cells (Fig. 3B), supporting the finding that $\alpha, \beta$-thujone triggers canonical apoptosis. In JAR cells, the expression of the anti-apoptotic proteins, MCL-1, $B C L 2$, and BCL2L1, were decreased, whereas that of the pro-apoptotic cleaved form of PARP was stimulated by $\alpha, \beta$-thujone (Fig. 3B). To comprehensively elucidate the mechanisms of apoptosis by the anti-apoptotic proteins, the interplay between proteasome activities and MCL-1 expression followed by a proteasome inhibitor were investigated in choriocarcinoma cells. The expression level of MCL- 1 was reduced in $\alpha, \beta$-thujone treated cells; however, pretreatment with MG-132 mitigated the $\alpha, \beta$ thujone-induced MCL-1 inhibition in both JEG3 and JAR cells (Fig. 3C and E). We also evaluated proteasome activity via chymotrypsin, caspase, and the trypsinlike protease activity associated with the proteasome 


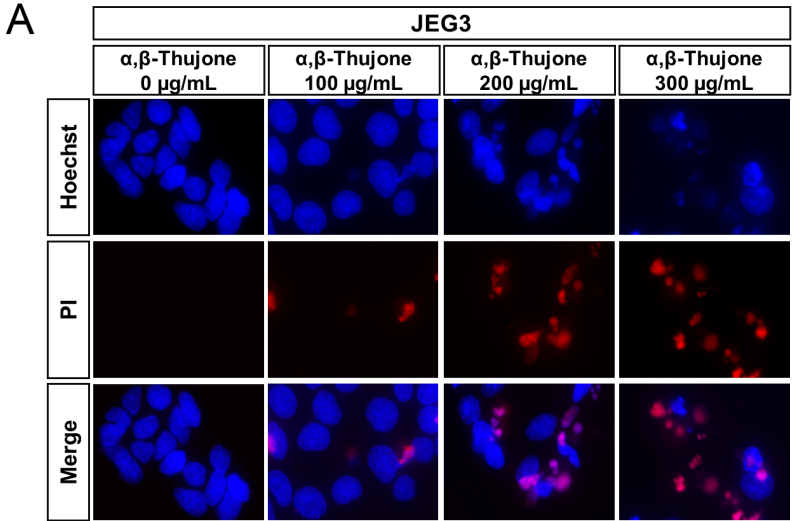

B
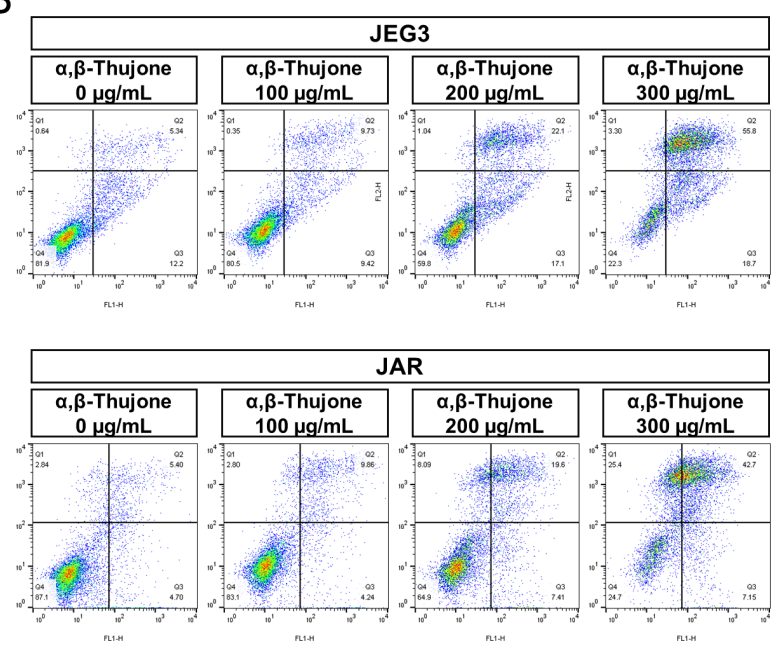

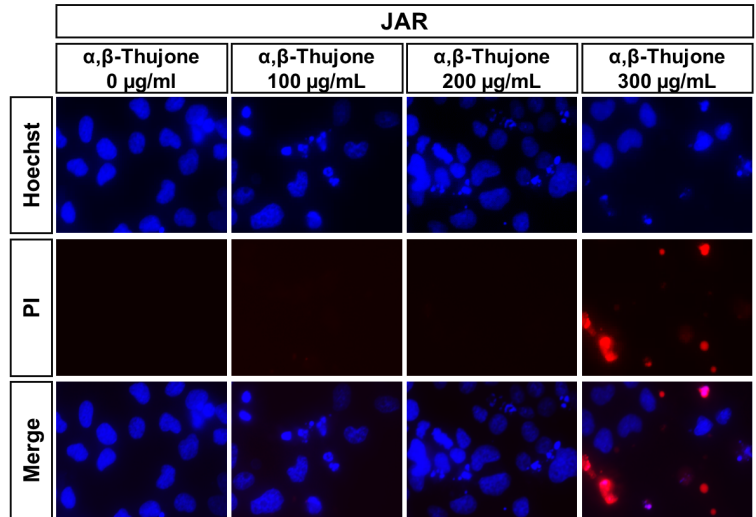

C

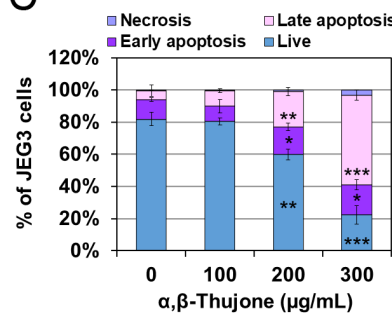

D

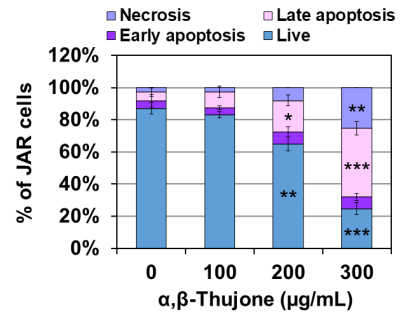

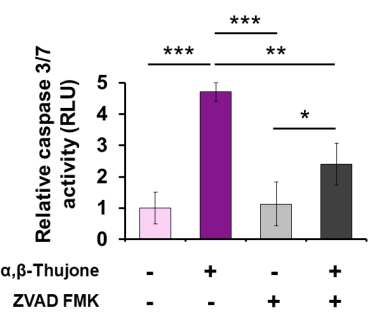

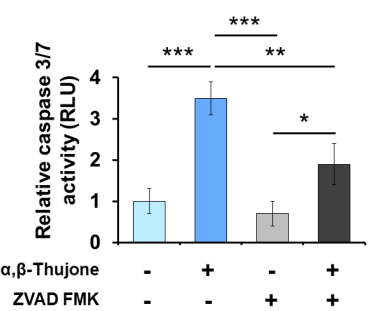

Figure 2 Cell death modality by $\alpha, \beta$-thujone in choriocarcinoma cells. (A) To analyze the cell death modality induced by $\alpha, \beta$-thujone, Hoechst and PI staining (Blue, Hoechst; Red, Propidium lodide) were performed to determine the morphological characteristics of JEG3 (left panel) and JAR (right panel) choriocarcinoma cells. (B) To support Hoechst and PI analysis, flow cytometry was employed to determine the patterns in cell death in response to $\alpha, \beta$-thujone in JEG3 (upper panel) and JAR (lower panel) cells. (C) Quantification of the results from Annexin and PI staining in JEG3 (upper panel) and JAR (lower panel) cells. (D) The effect of $300 \mu \mathrm{g} / \mathrm{mL}$ of $\alpha, \beta$-thujone on caspase $3 / 7$ activity in JEG3 (upper panel) and JAR (lower panel) cells was analyzed by ZVAD FMK, a pan-caspase inhibitor. Results are expressed as mean \pm s.D. of three independent experiments. Asterisk indicates a statistically significant difference compared to the control, as analyzed by Dunnett's test, one-, or two-way ANOVA $\left({ }^{*} P<0.05 ;{ }^{* *} P<0.01 ;{ }^{* * *} P<0.001\right)$.

complex in choriocarcinoma cells. Consistent with the Western blot results, chymotrypsin-like $\beta 5$-subunit, trypsin-like $\beta 2$-subunit, and caspase-like $\beta 1$-subunit in proteasome were slightly increased by $\alpha, \beta$-thujone in the JEG3 and JAR choriocarcinoma cell lines (Fig. 3D and $F$ ). Altogether, our results support our hypothesis that $\alpha, \beta$-thujone induced the regulation of proteasome activities which affect the proteasomal degradation of the anti-apoptotic protein, eventually leading to apoptosis in choriocarcinoma cells.

\section{$\alpha, \beta$-Thujone disrupts mitochondrial metabolic homeostasis and mitochondrial calcium transport in human placental choriocarcinoma cells}

As $\alpha, \beta$-thujone was found to mainly induce intrinsic apoptosis, we sought to demonstrate its effects on mitochondrial function and metabolic homeostasis; this is because the mitochondrion is the major organ for the mediation of intrinsic apoptosis in cancer cells. As shown in Fig. 4A, the depolarization of the mitochondrial membrane in JEG3 cells was significantly increased by treatment with $\alpha, \beta$-thujone in a dose-dependent manner (Fig. 4A). Aligning with these results, $\alpha, \beta$-thujone also stimulated the depolarization of mitochondrial membrane potential in JAR cells (Fig. 4B). Thus, the effects of $\alpha, \beta$-thujone on calcium homeostasis was determined by using fluorescence mitochondrial calcium tracker in JEG3 and JAR cells. Mitochondrial calcium release was increased in response to $\alpha, \beta$-thujone treatment in JEG3 and JAR cells, which imply that the calcium channels on the mitochondria were opened through IP3 receptors under $\alpha, \beta$-thujone-mediated cellular stresses (Fig. 4C). As our findings revealed the anti-cancer effects of 
A

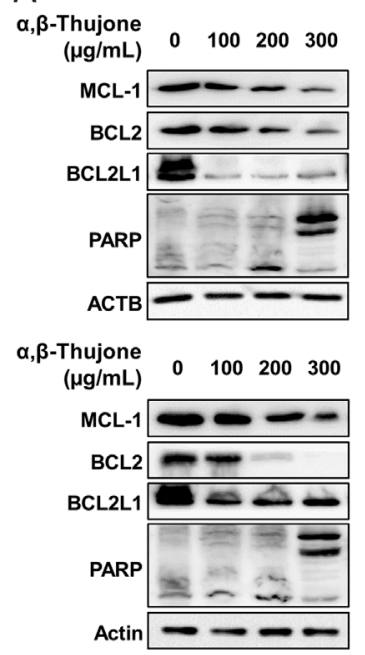

C

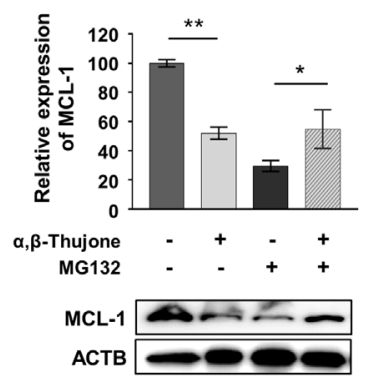

B
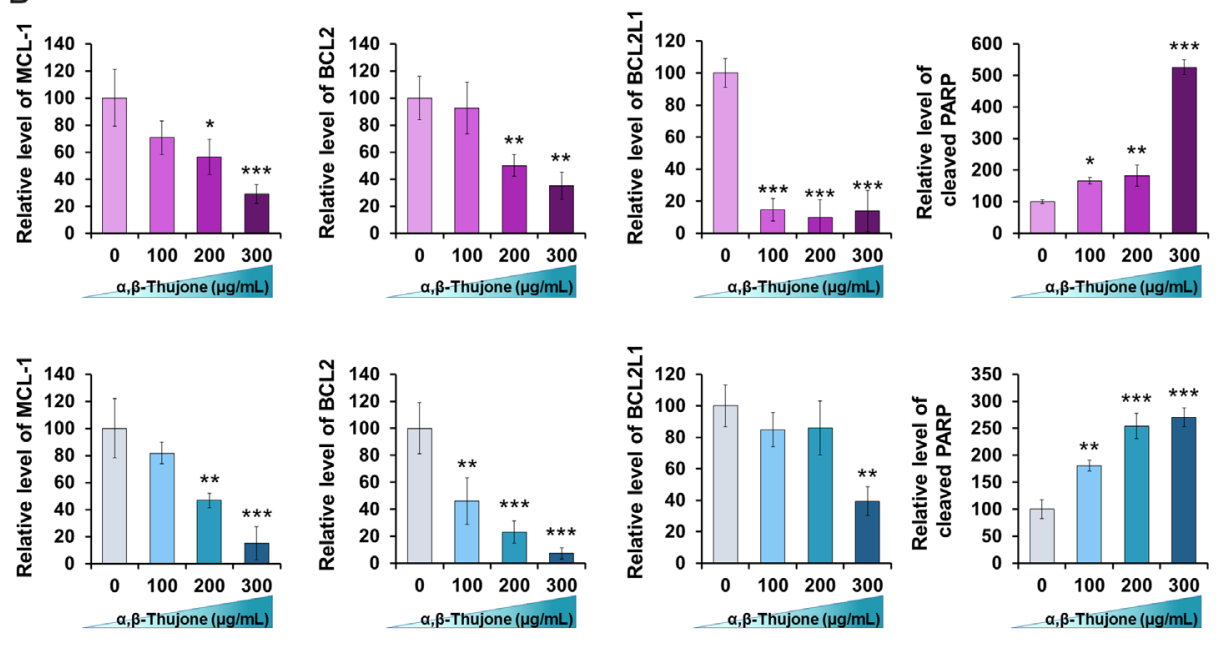

$\mathrm{D}$

E
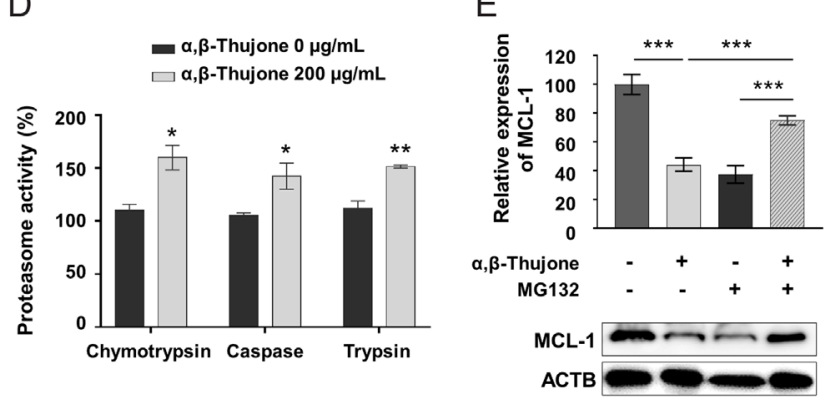

$\mathrm{F}$

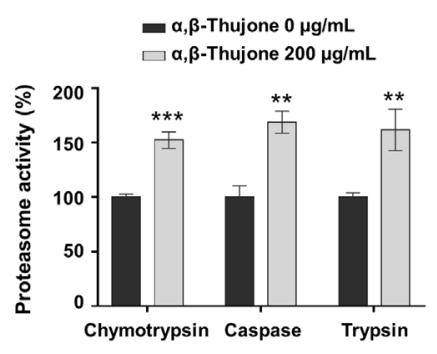

Figure 3 Effects of $\alpha, \beta$-thujone on the intrinsic apoptosis regulators in choriocarcinoma cells. (A) The dose-dependent $(0,100,200,300 \mu \mathrm{g} / \mathrm{mL})$ effect of $\alpha, \beta$-thujone on apoptosis-related proteins in JEG3 (upper panel) and JAR (lower panel) cells was determined by Western blot analysis. (B) Densitometry analysis was conducted to determine the fold differences in protein expression in JEG3 (upper panel) and JAR (lower panel) cells. (C) The protein expression level of MCL-1 in response to treatment with $\alpha, \beta$-thujone and the proteasome inhibitor, MG- 132 , in JEG3 cells was analyzed by Western blot assay. (D) The effect of $\alpha, \beta$-thujone on proteasome activities, including those of chymotrypsin-like, caspase-like, and trypsin-like proteins, was analyzed by a fluorometric $20 S$ proteasome assay in JEG3 cells. (E) The protein expression level of MCL-1 in response to treatment with $\alpha, \beta$-thujone and the proteasome inhibitor, MG-132, in JAR cells was analyzed via Western blot assay. (F) The effect of $\alpha, \beta$-thujone on proteasome activities, including those of chymotrypsin-like, caspase-like, and trypsin-like proteins, was analyzed by a fluorometric $20 S$ proteasome assay in JAR cells. Results are expressed as mean \pm S.D. of three independent experiments. Asterisk indicates a statistically significant difference compared to the control, as analyzed by Dunnett's test, one-, or two-way ANOVA $\left({ }^{*} P<0.05\right.$; ${ }^{* *} P<0.01$; $* * * P<0.001)$.

$\alpha, \beta$-thujonethrough the disruption of cellular homeostasis, we analyzed the metabolic profiling according to $\alpha, \beta-$ thujone treatment in choriocarcinoma cells (Fig. 4D). To analyze the metabolic landscape in response to $\alpha, \beta-$ thujone treatment, oligomycin, FCCP, and antimycin A and rotenone were sequentially added to JEG3 and JAR cells to serve as the ATP synthase inhibitor, protonophore uncoupler, and electron transport inhibitors, respectively, after $48 \mathrm{~h}$ of $\alpha, \beta$-thujone treatment. In both JEG3 and JAR cells, basal respiratory levels were reduced by treatment with $\alpha, \beta$-thujone and ATP production and maximal respiration were completely disrupted by treatment with $300 \mu \mathrm{g} / \mathrm{mL}$ of $\alpha, \beta$-thujone (Fig. 4E). The energy phenotypes in JEG3 and JAR cells were also altered, implying that $\alpha, \beta$-thujone triggers energy deprivation in choriocarcinoma cells (Fig. 4F). Overall, cellular metabolism was evidently overturned by $\alpha, \beta$-thujone in choriocarcinoma cells, suggesting that it could be potentially involved in the major mechanisms of the anticancer property of $\alpha, \beta$-thujone in choriocarcinoma cells.

\section{$\alpha, \beta$-Thujone triggers $E R$ stress in human placental choriocarcinoma cells}

As intrinsic apoptosis and proteasome regulation were found to be affected by $\alpha, \beta$-thujone, we hypothesized that ER stress may be involved in the $\alpha, \beta$-thujone-mediated anti-cancer potential. Thus, we opted to perform Western blot to determine the effect of $\alpha, \beta$-thujone on ER stress in choriocarcinoma cells (Fig. $5 \mathrm{~A}$ and $\mathrm{B}$ ). As shown in Fig. 5, the expression level of the ER luminal chaperone, HSPA5 (also known as GRP78), was increased by 2.1fold in JEG3 cells treated with $300 \mu \mathrm{g} / \mathrm{mL} \alpha, \beta$-thujone. Moreover, under ER stress, the expression level of the 
A
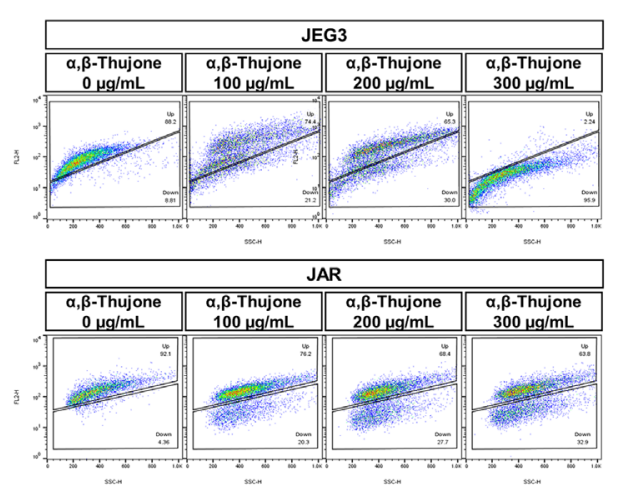

D

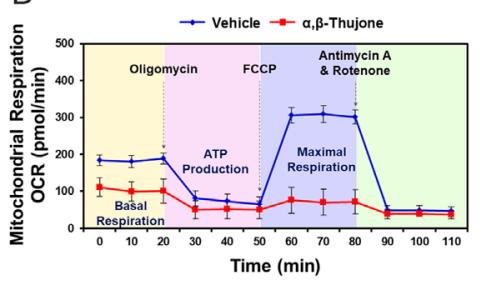

E
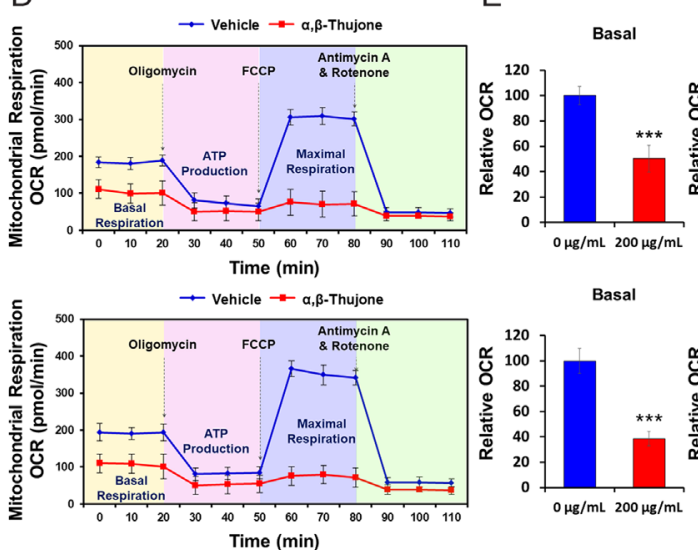

B
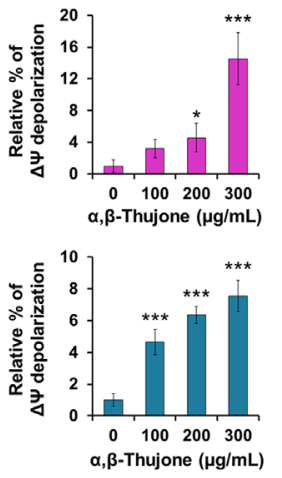

C
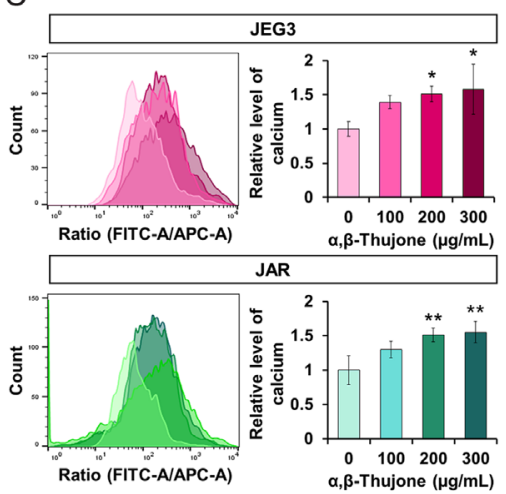

$\mathrm{F}$
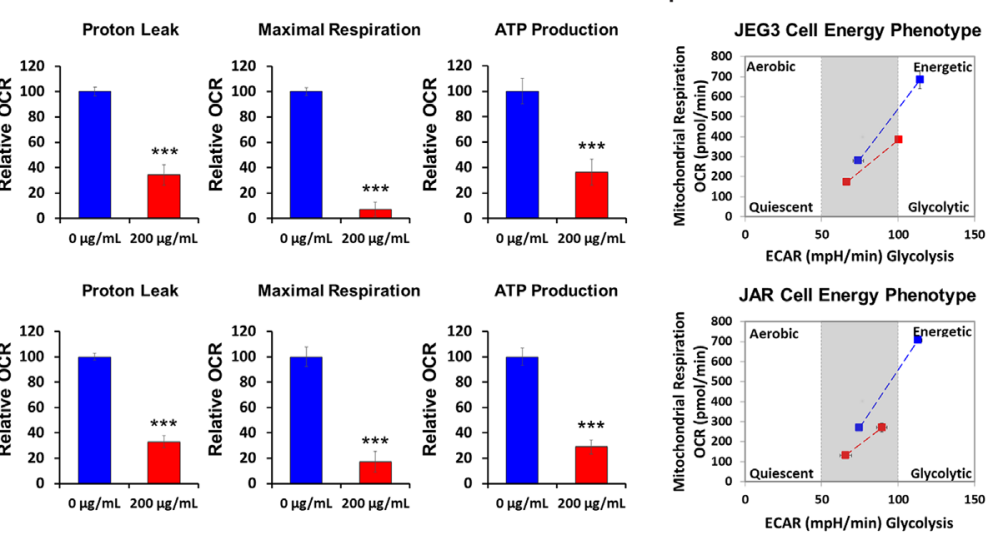

Figure $4 \alpha, \beta$-Thujone-induced mitochondrial deficiency and energy deprivation in choriocarcinoma cells. (A) The dose-dependent (0, 100, 200, $300 \mu \mathrm{g} / \mathrm{mL}$ ) effect of $\alpha, \beta$-thujone on mitochondrial membrane potential in JEG3 (upper panel) and JAR (lower panel) cells was analyzed by Green and JC-1 Red staining using a flow cytometer. (B) Quantification of the $\alpha, \beta$-thujone-mediated mitochondrial depolarization in JEG3 (upper panel) and JAR (lower panel) cells. (C) The effect of $\alpha, \beta$-thujone on mitochondrial calcium concentrations in JEG3 (upper panel) and JAR (lower panel) cells was determined by Rhod-2 AM staining and analyzed on a flow cytometer. (D) The $\alpha, \beta$-thujone-related metabolic profiling in JEG3 (upper panel) and JAR (lower panel) cells was revealed through seahorse analysis in response to treatment with oligomycin, FCCP, Antimycin A, and Rotenone. (E) Basal OCR, Proton Leak, Maximal respiration, and ATP production were analyzed as the metabolic parameters in JEG3 (upper panel) and JAR (lower panel) cells in response to treatment with $200 \mu \mathrm{g} / \mathrm{mL}$ of $\alpha, \beta$-thujone. (F) The energy phenotypes in JEG3 (upper panel) and JAR (lower panel) cells were obtained by seahorse assay following treatment with $200 \mu \mathrm{g} / \mathrm{mL}$ of $\alpha, \beta$-thujone. Results are expressed as mean \pm s.D. of three independent experiments. Asterisk indicates a statistically significant difference compared to the control, as analyzed by Dunnett's test, one-, or two-way ANOVA ( $\left.{ }^{*} P<0.05 ; * * P<0.01 ; * * * P<0.001\right)$.

UPR pathway inducer, EIF2AK3 (also known as PERK), was accumulated by four-fold in JEG3 cells treated with the highest concentration of $\alpha, \beta$-thujone. The expression of the multi-functional transcription factors, ATF4 and DDIT3 (also known as CHOP), were also increased by 1.7 - and 2.3-fold in JEG3 cells treated with $300 \mu \mathrm{g} / \mathrm{mL}$ $\alpha, \beta$-thujone. In JAR cells, the expression level of HSPA5 was significantly induced by $\alpha, \beta$-thujone treatment in a dose-dependent manner; however, the phosphorylation of EIF2AK3 was not affected by $\alpha, \beta$-thujone. The expression of the cytoplasmic transcriptional factor, ATF4, and nuclear translocation protein, DDIT3, were stimulated by 1.7 - and 3.4 -fold according to $\alpha, \beta$-thujone treatment in JEG3 cells. These results imply that the $\alpha, \beta$ thujone-associated anti-cancer activities are involved in ER stress, thereby leading to the disruption of cellular homeostasis and proteasome regulation, which result in apoptosis induction in JEG3 and JAR choriocarcinoma cells.

\section{Synergistic anti-cancer potential of the combination of $\alpha, \beta$-thujone and paclitaxel}

To elucidate the pharmaceutical properties of $\alpha, \beta$ thujone, we determined its chemosensitive effects against the conventional therapeutic reagent, paclitaxel, in choriocarcinoma cells. To optimize the single drug effect, 100 and $200 \mu \mathrm{g} / \mathrm{mL}$ of $\alpha, \beta$-thujone, which are less-toxic concentrations according to our previous results, were administered for $24 \mathrm{~h}$. In addition, we administered 0.1 and $0.5 \mu \mathrm{M}$ paclitaxel, which are also less-toxic concentrations for single treatment conditions. First, we demonstrated the cell death modality in both cells by combining the two drugs. Single treatment with 

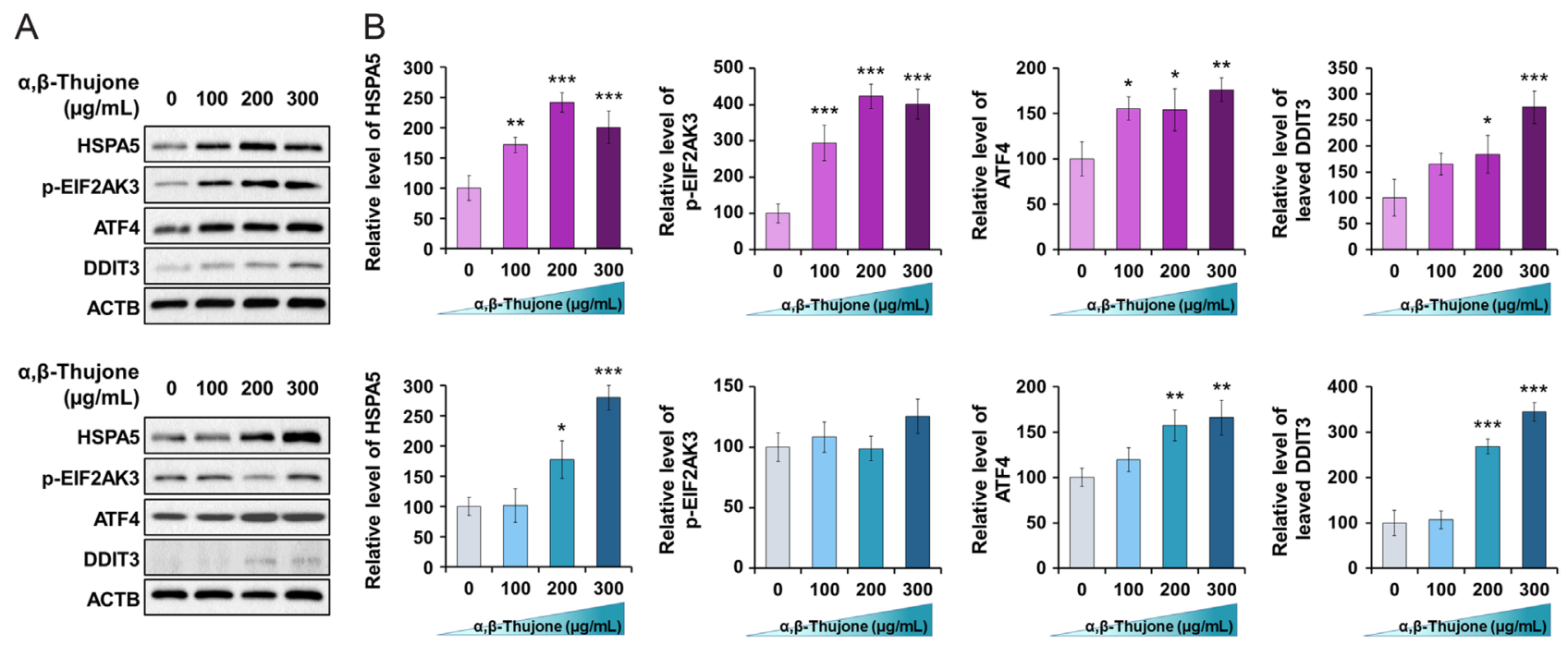

Figure 5 Effect of $\alpha, \beta$-thujone on ER stress-associated proteins in choriocarcinoma cells. (A) The dose-dependent $(0,100,200,300 \mu \mathrm{g} / \mathrm{mL})$ effect of $\alpha, \beta$-thujone on ER stress-associated proteins in JEG3 (upper panel) and JAR (lower panel) cells was determined by Western blot assay.

(B) Densitometry analysis was carried out to determine the fold differences in protein expression in JEG3 (upper panel) and JAR (lower panel) cells, which were quantified by Image J software. Results are expressed as mean \pm S.D. of three independent experiments. Asterisk indicates a statistically significant difference compared to the control, as analyzed by Dunnett's test, one-, or two-way ANOVA $(* P<0.05 ; * * P<0.01$; $* * * P<0.001)$.

$\alpha, \beta$-thujone or paclitaxel mildly triggered apoptosis; however, combination treatment with both drugs induced $100 \%$ necrotic cell death and late apoptotic cell death in JEG3 and JAR cells, respectively (Fig. 6A). In different conditions, this combination regimen displayed significant synergistic anti-cancer effects in both JEG3 and JAR cells (Fig. 6B). To support our results and clarify our hypothesis, we calculated the combination index (Cl) and fraction affected (FA) values. Aligning with our previous results, all combination conditions had a $\mathrm{Cl}$ value less than 1 . Such findings provide a clear interpretation of the synergistic drug effect exhibited by the combination of $\alpha, \beta$-thujone and paclitaxel in choriocarcinoma cells (Fig. 6C). Together, we identified not only the single drug effects of $\alpha, \beta$-thujone, but also its sensitization effect against paclitaxel in choriocarcinoma cells. These findings indicate the broad pharmaceutical potential of $\alpha, \beta$-thujone in choriocarcinoma cells.

\section{Discussion}

Through the current study, we could verify that $\alpha, \beta$ thujone ( $70 \%$ of $\alpha$-thujone and $10 \%$ of $\beta$-thujone) actively displays anti-cancer effects against placental choriocarcinoma cells by inducing apoptosis via the mitochondrial-mediated intrinsic pathway. In particular, $\alpha, \beta$-thujone was found to induce global mitochondrial disruption by causing loss of MMP and calcium overload, resulting in metabolic disruption and apoptosis induction. Overall, our results imply that $\alpha, \beta$-thujone attenuates choriocarcinoma through mitochondrial defect-induced energy deprivation and cellular stresses, which may trigger apoptosis induction in the human placental choriocarcinoma cell lines (Fig. 7).

Previously, plant-derived phytochemicals were suggested as promising chemotherapeutic alternatives that display anti-cancer potential with mechanistic approaches that target placental choriocarcinoma cells. For instance, extracts of Ginko biloba (EGb) exhibited inhibitory effects in the human choriocarcinoma cell, JEG3, and curcumin suppressed the migration and proliferation of placental choriocarcinoma cells, thereby inducing apoptosis via the ERK and MAPK pathways (Lim et al. 2016). Among numerous phytochemicals, $\alpha$-thujone and $\beta$-thujone are major components of thuja oil. Previously, thuja oil was reported as an anti-cancer compound as it inhibited proliferation, caused metastasis, and induced apoptosis in melanoma, lung cancer, and hepatocellular carcinoma (Sunila \& Kuttan 2006, Kumar et al. 2007, Biswas et al. 2011, Sunila et al. 2011, Mukherjee et al. 2013). In the present study, we could clearly demonstrate the pro-apoptotic functions of $\alpha, \beta$ Thujone in placental choriocarcinoma cells via caspasedependent mechanism and intracellular stress. Previously, thuja was found to trigger apoptosis in cancer cells via ROS production and p53 activation, resulting in caspaseassociated apoptosis in mammary epithelial carcinoma (Saha et al. 2014), thereby aligning with our results. In addition, the induction of cell cycle arrest and apoptosis in the lung adenocarcinoma cell line with caspase 3-dependency and ROS-independency was identified as the anti-cancer mechanism of thuja and flavonol (Mukherjee et al. 2014). However, information on the mechanisms whereby $\alpha, \beta$-thujone exhibits its anti-cancer 
A
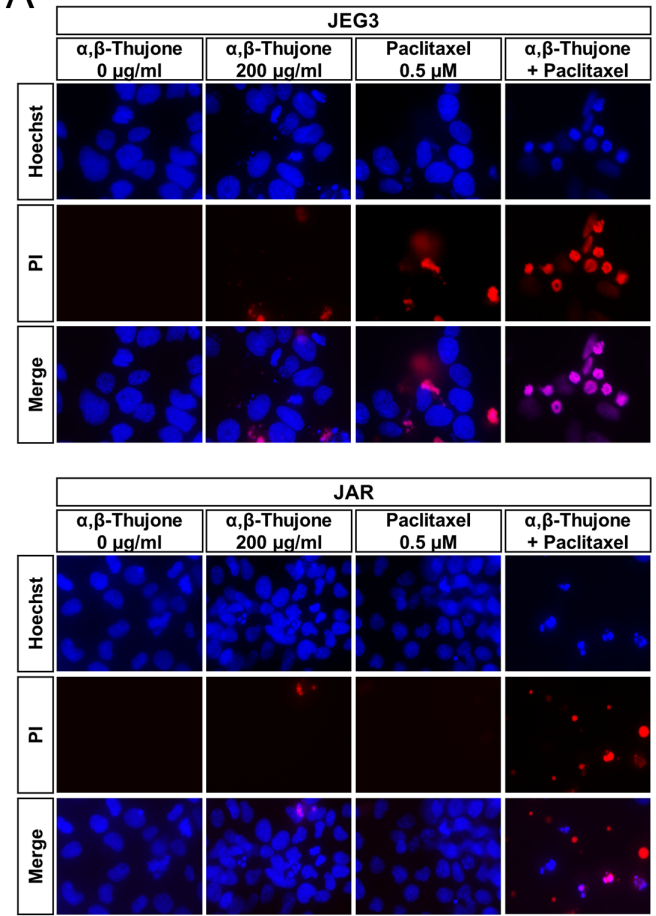

B

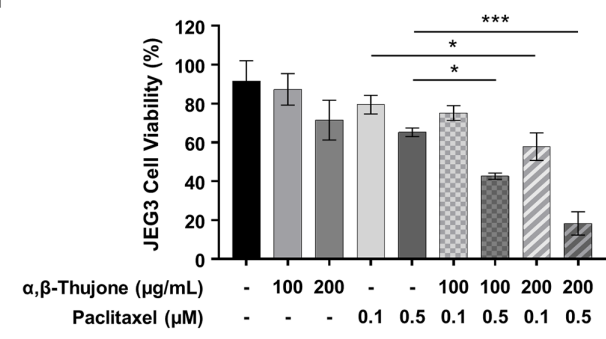

$\begin{array}{lllllllllllll}\text { Paclitaxel }(\mu \mathrm{M}) & - & - & - & 0.1 & 0.5 & 0.1 & 0.5 & 0.1 & 0.5\end{array}$

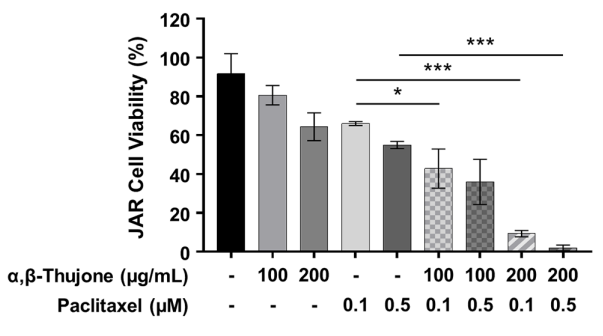

C
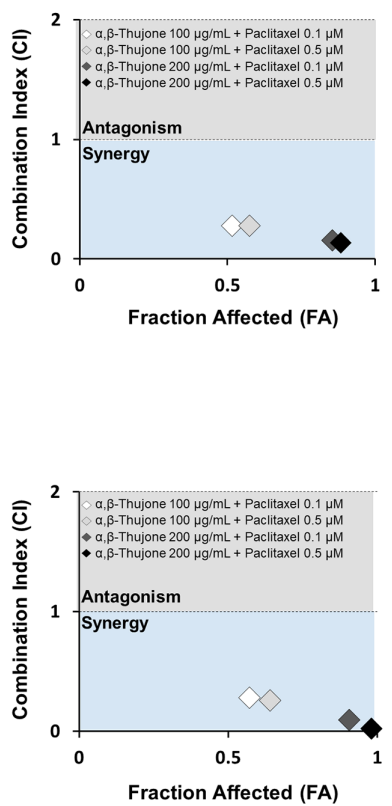

Figure 6 Effect of the chemosensitivity of $\alpha, \beta$-thujone against paclitaxel treatment in choriocarcinoma cells. (A) The effect of the combination of $\alpha, \beta$-thujone and paclitaxel on nuclear condensation in JEG3 (upper panel) and JAR (lower panel) cells was determined by Hoechst and PI staining (Blue, Hoechst; Red, Propidium lodide). (B) The synergistic anti-cancer effects of the combination of $\alpha, \beta$-thujone and paclitaxel in JEG3 (upper panel) and JAR (lower panel) cells were determined using a cell viability assay. (C) The synergistic anti-cancer potential of the combination of $\alpha, \beta$-thujone and paclitaxel in JEG3 (upper panel) and JAR (lower panel) cells were determined by calculating the combination index $(\mathrm{Cl})$ using the CompuSyn software. Results are expressed as mean \pm s.D. of three independent experiments. Asterisk indicates a statistically significant difference compared to the control, as analyzed by Dunnett's test, one-, or two-way ANOVA $\left({ }^{*} P<0.05 ;{ }^{* * *} P<0.001\right)$.

effects is limited, and its mechanism in choriocarcinoma is yet to be elucidated. Thus, the present study is the first to comprehensively reveal the mechanisms of $\alpha, \beta-$ thujone based on its mitochondrial functions, ER stress, and proteasome activities in choriocarcinoma cells.

The interplay among mitochondria, ER stress, and apoptosis has been of major interest in research owing to the mechanisms of anti-cancer, anti-inflammation, and immune regulations. Although protein regulation by the proteasome is tightly regulated by ER stress under reversible control, the sustained ER stress causes apoptosis with specific characteristics, including DNA fragmentation, cytochrome C release, and caspase activation. In addition, the ER stress-mediated apoptosis mechanisms that are associated with proteasome activation have been discovered (Egger et al. 2007), and several proteins, including caspases, DDIT3, JNK, and BCL2 family proteins, have been described as ER-stress related cell death molecules (Hacki et al. 2000, Ferri \& Kroemer 2001, Ruiz-Vela et al. 2005). Consistent with previous investigations, our results demonstrate that the anti-cancer activity of $\alpha, \beta$-thujone was involved in ER and mitochondrial stress, resulting in the activation of caspases and the degradation of the anti-apoptotic protein, which eventually promote proteasome-associated apoptosis.
Besides being the first study to elucidate the effect of $\alpha, \beta$-thujone on ER stress and its emerging mechanisms, this study has also clarified its effects on mitochondrial deficiency. As the mitochondrion is the central organelle for regulating the bioenergetic role and metabolic transition, anti-cancer drugs that target the mitochondria have been thoroughly described previously. In some studies, the researchers exploited the modified mitochondrial target molecules by using tri-phenyl-phosphonium (TPP) structures to enhance the functionality of targets on mitochondrial targeting signal (MTS). The TPP-related molecules were found to display high efficacy for the inhibition of cancer stem cells via oxidative phosphorylation (OXPHOS) and the oxygen consumption rate (OCR) (Ozsvari et al. 2018). As metabolic reprogramming via the mitochondria is emerging as a potent therapeutic strategy, we suggest the integrated anti-cancer mechanism of $\alpha, \beta$-thujone based on the mitochondrial damages it induces. Although studies on the metabolic profiling of choriocarcinoma have not been performed, many studies have been conducted according to bioenergetic analysis to elucidate the anti-cancer efficacy in gynecological cancer (Dier et al. 2014). In addition, aerobic glycolysis has long been described as the bioenergetic pathway 


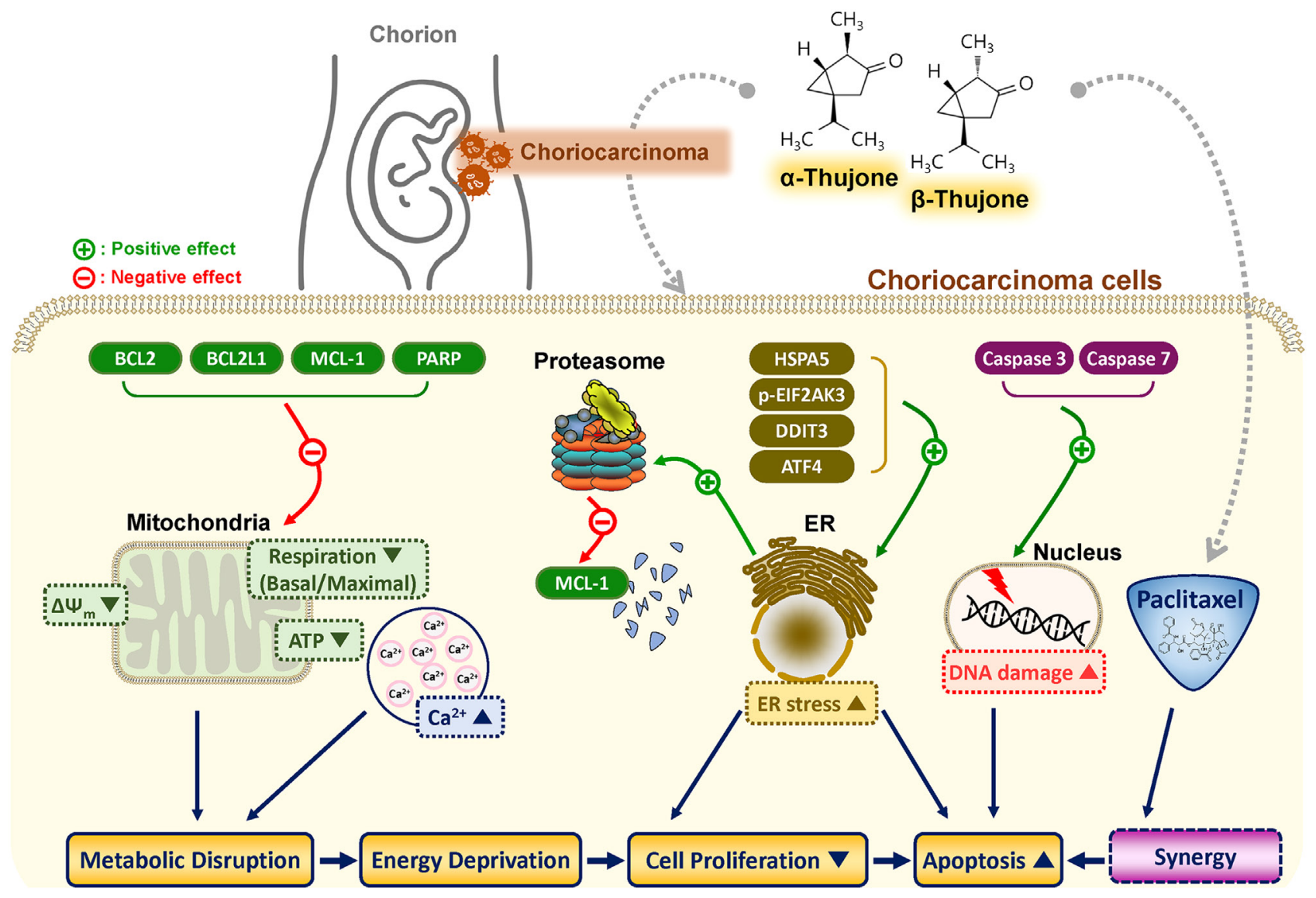

Figure 7 Schematic diagram of the $\alpha, \beta$-thujone-associated anti-cancer mechanisms in choriocarcinoma cells.

required for tumorigenesis. Furthermore, some of the small molecules were identified as cancer cell inhibitors through the targeting of mitochondrial OXPHOS (Sullivan \& Chandel 2014). For instance, the anti-cancer mechanisms of Berberine, IACS-10759, and AG311 as mitochondrial complex I inhibitors were demonstrated (Turner et al. 2008, Bastian et al. 2017); atpenins and rosamine as complex II inhibitors were described (Miyadera et al. 2003, Lim et al. 2014); and bupivacaine and FCCP as mitochondrial uncouplers were identified (Cela et al. 2010, To et al. 2010). $\alpha$-Thujone was also elucidated as a ROS inducer for the anti-cancer activity against malignant glioblastoma. Such finding implies that thujone might be involved as a mitochondria and metabolic disruptor of cancer cells (Pudelek et al. 2019). In accordance with a previous study, our findings clearly revealed that $\alpha, \beta$-thujone attenuates mitochondrial functions via mitochondrial depolarization and calcium overload. This was also clarified by the reduction in basal respiration, ATP production, and mitochondrial uncoupler in $\alpha, \beta$-thujone-treated choriocarcinoma cells and the alterations in energy phenotypes. Together, we suggest that the metabolic disruption induced by $\alpha, \beta$ thujone causes energy deprivation of choriocarcinoma cells, which eventually contribute to the inhibition of proliferation and the promotion of apoptosis of cancer cells.

Besides the single drug effects of $\alpha, \beta$-thujone in choriocarcinoma cells, we identified the synergistic effects it exhibits with paclitaxel to overcome drug resistance caused by conventional chemotherapy. In clinical chemotherapy, the EMA/CO regimen is a wellaccepted strategy for choriocarcinoma treatment (Bower et al. 1997). However, 20 to $30 \%$ of high-risk patients are resistant to this multidrug regimen. Accordingly, other therapeutic strategies and drug combinations must be developed. Previously, paclitaxel was suggested to increase the therapeutic success in choriocarcinoma patients (Joshua et al. 2004). In fact, tumor progression was found to be significantly reduced by paclitaxel in choriocarcinoma patients. Moreover, the acquired resistance mechanisms of taxanes in cancer cells have been adequately described in different studies (Wang et al. 2014). Thus, we opted to determine the effect of combining $\alpha, \beta$-thujone and paclitaxel as a therapeutic strategy to overcome side effects and the acquired drug resistance in choriocarcinoma cells.

Insummary, $\alpha, \beta$-thujonecanattenuatechoriocarcinoma by abrogating cell proliferation and inducing apoptosis via caspase-dependent intrinsic pathways. Herein, we 
demonstrated that $\alpha, \beta$-thujone inhibits the anchorageindependent growth of choriocarcinoma cells by completely reducing JEG3 and JAR tumor spheroids. Furthermore, we identified that $\alpha, \beta$-thujone triggers metabolic disruption by ER and mitochondria stress, which result in energy deprivation and eventually contribute to the attenuation of choriocarcinoma cells. By revealing the synergistic anti-cancer effects exhibited by $\alpha, \beta$-thujone when combined with paclitaxel, we could demonstrate its pharmaceutical potential, beyond its mono effect, against choriocarcinoma. Further in vivo validation of the anti-cancer mechanisms of $\alpha, \beta$-thujone may be needed to support our conclusion. Currently, our in vitro study provided important perspectives into the comprehensive pharmacological potential of $\alpha, \beta$ thujone against choriocarcinoma for further extended studies. Altogether, our study suggests that $\alpha, \beta$-thujone is a novel natural pharmacological compound against human placental choriocarcinoma.

\section{Declaration of interest}

The authors declare that there is no conflict of interest that could be perceived as prejudicing the impartiality of the research reported.

\section{Funding}

This research was supported by a grant of the National Research Foundation of Korea (NRF) grant, funded by the Ministry of Science and ICT (MSIT) (grant number: 2018R1C1B6009048).

\section{Author contribution statement}

G S, W L, and J-Y L conceived and designed the culture experiments, the cell culture methodology, and all other experiments. J-Y L and H P collected experimental samples and conducted all experiments. J-Y L, W L, and G S analyzed, interpreted the data and contributed to the development of the manuscript. All authors contributed to its critical review and agreed on the final version.

\section{References}

Bastian A, Matsuzaki S, Humphries KM, Pharaoh GA, Doshi A, Zaware N, Gangjee A \& Ihnat MA 2017 AG311, a small molecule inhibitor of complex I and hypoxia-induced HIF-1alpha stabilization. Cancer Letters 388 149-157. (https://doi.org/10.1016/j.canlet.2016.11.040)

Biswas R, Mandal SK, Dutta S, Bhattacharyya SS, Boujedaini N \& KhudaBukhsh AR 2011 Thujone-rich fraction of Thuja occidentalis demonstrates major anti-cancer potentials: evidences from in vitro studies on A375 cells. Evidence-Based Complementary and Alternative Medicine 2011 568148. (https://doi.org/10.1093/ecam/neq042)

Bower M, Newlands ES, Holden L, Short D, Brock C, Rustin GJ, Begent RH \& Bagshawe KD $1997 \mathrm{EMA} / \mathrm{CO}$ for high-risk gestational trophoblastic tumors: results from a cohort of 272 patients. Journal of Clinical Oncology 15 2636-2643. (https://doi.org/10.1200/JCO.1997.15.7.2636)

Cela O, Piccoli C, Scrima R, Quarato G, Marolla A, Cinnella G, Dambrosio M \& Capitanio N 2010 Bupivacaine uncouples the mitochondrial oxidative phosphorylation, inhibits respiratory chain complexes I and III and enhances ROS production: results of a study on cell cultures. Mitochondrion 10 487-496. (https://doi.org/10.1016/j. mito.2010.05.005)

Chang LC, Song LL, Park EJ, Luyengi L, Lee KJ, Farnsworth NR, Pezzuto JM \& Kinghorn AD 2000 Bioactive constituents of Thuja occidentalis. Journal of Natural Products 63 1235-1238. (https://doi.org/10.1021/ np0001575)

Dadlani R, Furtado SV, Ghosal N, Prasanna KV \& Hegde AS 2010 Unusual clinical and radiological presentation of metastatic choriocarcinoma to the brain and long-term remission following emergency craniotomy and adjuvant EMA-CO chemotherapy. Journal of Cancer Research and Therapeutics 6 552-556. (https://doi.org/10.4103/0973-1482.77069)

Dier U, Shin DH, Hemachandra LP, Uusitalo LM \& Hempel N 2014 Bioenergetic analysis of ovarian cancer cell lines: profiling of histological subtypes and identification of a mitochondria-defective cell line. PLoS ONE 9 e98479. (https://doi.org/10.1371/journal.pone.0098479)

Egger L, Madden DT, Rheme C, Rao RV \& Bredesen DE 2007 Endoplasmic reticulum stress-induced cell death mediated by the proteasome. Cell Death and Differentiation 14 1172-1180. (https://doi.org/10.1038/ sj.cdd.4402125)

Ferri KF \& Kroemer G 2001 Organelle-specific initiation of cell death pathways. Nature Cell Biology 3 E255-E263. (https://doi.org/10.1038/ ncb1101-e255)

Fournier T 2016 Human chorionic gonadotropin: different glycoforms and biological activity depending on its source of production. Annales d'Endocrinologie 77 75-81. (https://doi.org/10.1016/j. ando.2016.04.012)

Frenkel M, Mishra BM, Sen S, Yang P, Pawlus A, Vence L, Leblanc A, Cohen L, Banerji P \& Banerji P 2010 Cytotoxic effects of ultra-diluted remedies on breast cancer cells. International Journal of Oncology 36 395-403. (https://doi.org/10.3892/ijo_00000512)

Gude NM, Roberts CT, Kalionis B \& King RG 2004 Growth and function of the normal human placenta. Thrombosis Research 114 397-407. (https://doi.org/10.1016/j.thromres.2004.06.038)

Hacki J, Egger L, Monney L, Conus S, Rosse T, Fellay I \& Borner C 2000 Apoptotic crosstalk between the endoplasmic reticulum and mitochondria controlled by Bcl-2. Oncogene 19 2286-2295. (https:// doi.org/10.1038/sj.onc.1203592)

Handschuh K, Guibourdenche J, Tsatsaris V, Guesnon M, Laurendeau I, Evain-Brion D \& Fournier T 2007 Human chorionic gonadotropin produced by the invasive trophoblast but not the villous trophoblast promotes cell invasion and is down-regulated by peroxisome proliferatoractivated receptor-gamma. Endocrinology 148 5011-5019. (https://doi. org/10.1210/en.2007-0286)

Heller DS 2018 Update on the pathology of gestational trophoblastic disease. APMIS 126 647-654. (https://doi.org/10.1111/apm.12786)

Jiao L, Ghorani E, Sebire NJ \& SeckI MJ 2016 Intraplacental choriocarcinoma: systematic review and management guidance. Gynecologic Oncology 141 624-631. (https://doi.org/10.1016/j.ygyno.2016.03.026)

Joshua AM, Carter JR \& Beale P 2004 The use of taxanes in choriocarcinoma; a case report and review of the literature. Gynecologic Oncology $\mathbf{9 4}$ 581-583. (https://doi.org/10.1016/j.ygyno.2004.05.036)

Kang YJ, Oh JH, Yoon Y, Kim EJ, Kim DY \& Kang HS 2002 Hepatic metastasis from choriocarcinoma: angiographic findings in two cases. Korean Journal of Radiology 3 260-263. (https://doi.org/10.3348/kjr.2002.3.4.260)

Kumar KB, Sunila ES, Kuttan G, Preethi KC, Venugopal CN \& Kuttan R 2007 Inhibition of chemically induced carcinogenesis by drugs used in homeopathic medicine. Asian Pacific Journal of Cancer Prevention 8 98-102.

Lee JY, Talhi O, Jang D, Cerella C, Gaigneaux A, Kim KW, Lee JW, Dicato M, Bachari K, Han BW et al. 2018 Cytostatic hydroxycoumarin OT52 induces ER/Golgi stress and STAT3 inhibition triggering non-canonical cell death and synergy with $\mathrm{BH} 3$ mimetics in lung cancer. Cancer Letters 416 94-108. (https://doi.org/10.1016/j.canlet.2017.12.007)

Lim SH, Wu L, Kiew LV, Chung LY, Burgess K \& Lee HB 2014 Rosamines targeting the cancer oxidative phosphorylation pathway. PLOS ONE $\mathbf{9}$ e82934. (https://doi.org/10.1371/journal.pone.0082934)

Lim W, Jeong M, Bazer FW \& Song G 2016 Curcumin suppresses proliferation and migration and induces apoptosis on human placental choriocarcinoma cells via ERK1/2 and SAPK/JNK MAPK signaling pathways. Biology of Reproduction 95 83. (https://doi.org/10.1095/ biolreprod.116.141630)

Lim W, Ryu S, Bazer FW, Kim SM \& Song G 2018 Chrysin attenuates progression of ovarian cancer cells by regulating signaling cascades 
and mitochondrial dysfunction. Journal of Cellular Physiology 233 3129-3140. (https://doi.org/10.1002/jcp.26150)

Miyadera H, Shiomi K, Ui H, Yamaguchi $Y$, Masuma R, Tomoda $H$, Miyoshi H, Osanai A, Kita K \& Omura S 2003 Atpenins, potent and specific inhibitors of mitochondrial complex II (succinate-ubiquinone oxidoreductase). PNAS 100 473-477. (https://doi.org/10.1073/ pnas.0237315100)

Mukherjee A, Boujedaini N \& Khuda-Bukhsh AR 2013 Homeopathic Thuja 30C ameliorates benzo(a)pyrene-induced DNA damage, stress and viability of perfused lung cells of mice in vitro. Journal of Integrative Medicine 11 397-404. (https://doi.org/10.3736/jintegrmed2013054)

Mukherjee A, Sikdar S, Bishayee K, Boujedaini N \& Khuda-Bukhsh AR 2014 Flavonol isolated from ethanolic leaf extract of Thuja occidentalis arrests the cell cycle at G2-M and induces ROS-independent apoptosis in A549 cells, targeting nuclear DNA. Cell Proliferation 47 56-71. (https://doi.org/10.1111/cpr.12079)

Nabers J, Splinter TA, Wallenburg HC, Ten Kate FJ, Oosterom R \& Hilvering C 1990 Choriocarcinoma with lung metastases during pregnancy with successful delivery and outcome after chemotherapy. Thorax 45 416-418. (https://doi.org/10.1136/thx.45.5.416)

Ojeswi BK, Khoobchandani M, Hazra DK \& Srivastava MM 2010 Protective effect of Thuja occidentalis against DMBA-induced breast cancer with reference to oxidative stress. Human and Experimental Toxicology 29 369-375. (https://doi.org/10.1177/0960327110364150)

Ozsvari B, Sotgia F \& Lisanti MP 2018 Exploiting mitochondrial targeting signal(s), TPP and bis-TPP, for eradicating cancer stem cells (CSCs). Aging 10 229-240. (https://doi.org/10.18632/aging.101384)

Pudelek M, Catapano J, Kochanowski P, Mrowiec K, Janik-Olchawa N, Czyz J \& Ryszawy D 2019 Therapeutic potential of monoterpene alphathujone, the main compound of Thuja occidentalis L. essential oil, against malignant glioblastoma multiforme cells in vitro. Fitoterapia 134 172-181. (https://doi.org/10.1016/j.fitote.2019.02.020)

Ruiz-Vela A, Opferman JT, Cheng EH \& Korsmeyer SJ 2005 Proapoptotic BAX and BAK control multiple initiator caspases. EMBO Reports 6 379-385. (https://doi.org/10.1038/sj.embor.7400375)

Saha S, Bhattacharjee P, Mukherjee S, Mazumdar M, Chakraborty S, Khurana A, Nayak D, Manchanda R, Chakrabarty R, Das T et al. 2014 Contribution of the ROS-p53 feedback loop in thuja-induced apoptosis of mammary epithelial carcinoma cells. Oncology Reports $\mathbf{3 1}$ 1589-1598. (https://doi.org/10.3892/or.2014.2993)
Sullivan LB \& Chandel NS 2014 Mitochondrial reactive oxygen species and cancer. Cancer and Metabolism 2 17. (https://doi.org/10.1186/20493002-2-17)

Sunila ES \& Kuttan G 2006 A preliminary study on antimetastatic activity of Thuja occidentalis L.inmicemodel.ImmunopharmacologyandImmunotoxicology 28 269-280. (https://doi.org/10.1080/08923970600809017)

Sunila ES, Hamsa TP \& Kuttan G 2011 Effect of Thuja occidentalis and its polysaccharide on cell-mediated immune responses and cytokine levels of metastatic tumor-bearing animals. Pharmaceutical Biology 49 1065-1073. (https://doi.org/10.3109/13880209.2011.565351)

To MS, Aromataris EC, Castro J, Roberts ML, Barritt GJ \& Rychkov GY 2010 Mitochondrial uncoupler FCCP activates proton conductance but does not block store-operated $\mathrm{Ca}(2+)$ current in liver cells. Archives of Biochemistry and Biophysics 495 152-158. (https://doi.org/10.1016/j. abb.2010.01.004)

Turco MY \& Moffett A 2019 Development of the human placenta. Development 146 dev163428. (https://doi.org/10.1242/dev.163428)

Turner N, Li JY, Gosby A, To SW, Cheng Z, Miyoshi H, Taketo MM, Cooney GJ, Kraegen EW, James DE et al. 2008 Berberine and its more biologically available derivative, dihydroberberine, inhibit mitochondrial respiratory complex I: a mechanism for the action of berberine to activate AMP-activated protein kinase and improve insulin action. Diabetes $\mathbf{5 7}$ 1414-1418. (https://doi.org/10.2337/db07-1552)

Wang H, Vo T, Hajar A, Li S, Chen X, Parissenti AM, Brindley DN \& Wang Z 2014 Multiple mechanisms underlying acquired resistance to taxanes in selected docetaxel-resistant MCF-7 breast cancer cells. BMC Cancer 14 37. (https://doi.org/10.1186/1471-2407-14-37)

Wroblewska-Kurdyk A, Gnilka R, Dancewicz K, Grudniewska A, Wawrzenczyk C \& Gabrys B 2019 beta-Thujone and its derivatives modify the probing behavior of the peach potato aphid. Molecules $\mathbf{2 4}$ 1847. (https://doi.org/10.3390/molecules24101847)

Received 14 January 2020

First decision 25 February 2020

Revised manuscript received 26 March 2020

Accepted 2 April 2020 